\title{
AKAD KAFALAH DALAM SYARIAH CARD
}

Hardian Iskandar, M.H.

Fakultas Hukum Universitas Muhammadiyah Gresik

Hardianiskan@umg.ac.id

\begin{abstract}
Abstrak
Di Negara Indonesia terdapat dua system bank antara lain Bank konvensional dan Bank Syariah. Dari berbagai macam produk salah satunya adalah kartu kredit. Dalam bank syariah dikenal dengan syariah card yang Fungsinya tidak berbeda dengan kartu kredit konvensional, Yang membedakannya adalah pada kartu kredit konvensional menggunakan sistem bunga sebagai bentuk pengambilan keuntungan terhadap pelunasan tagihan yang dicicil dan Sedangkan syariah card berdasarkan pada prinsip kafalah, qardh, dan ijarah. Sebagaimana diatur dalam fatwa Fatwa Dewan Syariah Nasional Nomor 54/DSN-MUI/X/2006 tentang Syariah Card.
\end{abstract}

\section{Pendahuluan}

Di Indonesia Bank syariah berkembang dengan dasar pemikiran untuk memberikan pelayanan jasa perbankan kepada sebagian masyarakat Indonesia yang tidak dapat dilayani oleh bank konvensional yang menggunakan sistem bunga. Dengan diterapkannya prinsip syariah dan di Indonesia mayoritas muslim maka membuka peluang untuk peningkatakn disektor syariah.

Bank syariah memberikan layanan bebas bunga kepada para nasabahnya. Islam melarang kaum muslim untuk menarik atau membayar bunga dalam bentuk transaksi. Segala jenis bunga adalah riba. Istilah itu mencakup semua bentuk bunga, baik besar atau kecil, berganda atau tunggal. Dengan demikian sistem keuangan yang didasarkan atas ajaran Islam ditujukan untuk menghapus bunga dalam segala bentuknya. Larangan inilah yang membedakan bank dan lembaga keuangan Islam lainnya dengan kembaga keuangan konvensional. Produk perbankan syariah yang serupa dengan produk bank konvensional diantaranya adalah giro, tabungan, deposito, asuransi, reksa dana, dan kartu kredit(kartu pembiayaan).

Kartu kredit merupakan salah satu bentuk pembayaran non tunai yang makin marak digunakan oleh masyarakat Indonesia dari sisi keperaktisan dan juga sisi cicilan yang beraneka ragam yang mungkin dapat dikatakan mempermudah bagi nasabah dalam memenuhi kebutuhan hidupnya. Sebagaimana diatur oleh aturan Bank Indonesia Nomor 11/11/PBI/2009 tentang Penyelenggaraan Kegiatan Alat Pembayaran Dengan Menggunakan Kartu pasal 1 angka 4 yang mejelaskan Kartu Kredit adalah "Alat Pembayaran dengan Menggunakan Kartu (APMK) yang dapat digunakan untuk 
melakukan pembayaran atas kewajiban yang timbul dari suatu kegiatan ekonomi, termasuk transaksi pembelanjaan yang disepakati baik dengan pelunasan secara sekaligus (charge card) ataupun dengan pembayaran secara angsuran”. Sedangkan Kartu kredit syariah baru difatwakan kebolehannya melaui Fatwa Dewan Syariah Nasional Nomor 54/DSN- MUI/X/2006 tentang Syariah Card. Dalam Pembiayaan menggunakan kartu syariah menggunakan tiga skema akad, yaitu Kafalah, Qardh dan Ijarah. Dengan adanya produk syariah card yang dikeluarkan oleh perbankan syariah sebenarnya merupakan salah satu jalan untuk menarik minat masyarakat untuk menggunakan jasa perbankan syariah. Hal-hal tersebut di atas merupakan latar belakang diadakannya penelitian ini, yaitu karakteristik kafalah dan penyelesaian sengketa pada bank penerbit syariah card.

\section{Hasil dan Pembahasan}

\section{A. Akad kafalah dalam hukum syariah}

Akad adalah kesepakatan tertulis antara bank syariah atau Unit Usaha Syariah (UUS) dan pihak lain yang memuat adanya hak dan kewajiban bagi masing-masing pihak sesuai dengan prinsip syariah (Pasal 1 angka 13 UU Perbankan Syariah).

Akad kafalah berdasarkan fatwa yang dikeluarkan oleh Dewan Syariah Nasional dan Majelis Ulama Indonesia pada tahun 2000, yaitu melalui Fatwa Dewan Syariah Nasional Nomor 11/DSN-MUI/IV/2000. Akad kafalah berdasarkan penjelasan Pasal 1 ayat (1) huruf i Undang-Undang Perbankan Syariah merupakan akad pemberian jaminan yang diberikan satu pihak kepada pihak lain, di mana pemberi jaminan (kafil) bertanggung jawab atas pembayaran kembali utang yang menjadi hak penerima jaminan (makful). Kafalah dapat juga berarti mengalihkan tanggungjawab seseorang yang dijamin dengan berpegang pada tanggungjawab orang lain sebagai penjamin. Atas jasanya penjamin dapat meminta imbalan tertentu dari orang yang dijamin. kafalah berarti mengambil tanggung jawab atas pembayaran utang atau atas kehadiran seorang di pengadilan. Secara hukum, dalam kafalah, seseorang dari pihak ketiga menjadi penjamin atas pembayaran utang yang belum terlunasi oleh orang yang memiliki kewajiban pada awalnya. rukun kafalah sebagaimana yang disebutkan dalam terdiri atas:

1) Pihak penjamin/penanggung (kafil), dengan syarat baligh (dewasa), berakal sehat, berhak penuh melakukan tindakan hukum dalam urusan hartanya, dan rela (ridha) dengan tanggungan kafalah tersebut.

2) Pihak yang berhutang (makful 'anhu 'ashil), dengan syarat sanggup menyerahkan tanggungannya (piutang) kepada penjamin dan dikenal oleh penjamin.

3) Pihak yang berpiutang (makful lahu), dengan syarat diketahui identitasnya, dapat hadir pada waktu akad atau memberikan kuasa, dan berakal sehat. 
4) Obyek jaminan (makful bih), merupakan tanggungan pihak/orang yang berhutang (ashil), baik berupa uang, benda, maupun pekerjaan, bisa dilaksanakan oleh pejamin, harus merupakan piutang mengikat (luzim) yang tidak mungkin hapus kecuali setelah dibayar atau dibebaskan, harus jelas nilai, jumlah, dan spesifikasinya, tidak bertentangan dengan syari'ah (diharamkan).

Kafalah pada dasarnya adalah akad sukarela yang bernilai ibadah bagi penjamin karena termasuk kerja sama dalam kebajikan, dan penjamin berhak meminta gantinya kembali kepada terutang, sepantasnyalah ia tidak meminta upah atas jasanya tersebut, agar aman/jauh dari syubhat dengan syarat - syarat antara lain :

1) Dhamin, kafiil, atau zaim yaitu orang yang menjamin di mana ia disyaratkan sudah baligh, berakal, tidak dicegah untuk membelanjakan hartanya dengan kata lain ia merdeka untuk digunakan kepentingan apapun tanpa ada pihak yang membatasi kepentingan atau keleluasaan menggunakan harta tadi.

2) Madhmun Lahu adalah orang yang memberikan utang pada pihak madhmun anhu, madhmun lahu memiliki syarat bahwa piutangnya diketahui oleh orang yang menjamin. Sedangkan madhmun bih adalah hak, barang, atau utang itu sendiri yang dijadikan objek dan terutama pihak yang memberikan jaminan atau disebut juga dengan makful lahu harus mengetahui bahwa madhmun anhu memiliki hak yang belum ditunaikan kepada madhmun lahu.

3) Dan Shigat atau lafazh yang diucapkan pada saat ijab Kabul terjadinya proses penjaminan adalah berupa ucapan yang diucapkan dengan jelas dan menyiratkan akan kesanggupannya dan tak dikaitkan dengan apapun serta tak dibatasi oleh waktu .

4) Madmun 'anhu atau makhful 'anhu adalah orang yang berhutang.

5) madmun bih atau makhful bih adalah utang, barang atau orang, disyaratkan pada mafkul bih dapat diketahui dan tetap keadaannya, baik sudah tetap maupun akan tetap.

Upah atas jasa kafalah berupa pemberian uang dari pemegang kartu kepada bank syariah dianggap sebagai upah, dan untuk hukumnya diperbolehkan karena sebagai pengganti jasa. Atas pemberian kafalah

pihak bank syariah mendapatkan imbalan berupa biaya keanggotaan bulanan yang jumlah besarannya telah ditentukan sejak awal akad.

\section{B. Penyelesaian sengketa bila terjadi wanprestasi bagi pemegang syariah card.}

Pada dasarnya bank selaku memiliki kepentingan untuk mndapatkan keuntungan maka hal yang harus diperhatikan apabila terjadi keterlambatan bayar ataupun wanprestasi yang terjadi jika debitur lalai dalam menmenuhi prestasi dalam penggunaan 
kartu kredit syariah. wanprestasi menurut pasal 1243 KUHPer adalah Penggantian biaya, kerugian dan bunga karena tak dipenuhinya suatu perikatan mulai diwajibkan, bila debitur, walaupun telah dinyatakan Ialai, tetap Ialai untuk memenuhi perikatan itu, atau jika sesuatu yang harus diberikan atau dilakukannya hanya dapat diberikan atau dilakukannya dalam waktu yang melampaui waktu yang telah ditentukan"

Untuk penyelesaian sengketa yanng terjadi pada syariah card, dapat ditempuh dengan beberapa cara antara lain :

1. Penyelesaian sengketa melalui jalan musyawarah

Dalam penyelesaian sengketa melalui jalur musyawarah diharuskan pihak-pihak kembali pada poin-poin yang telah disepakati dan hal yang dipersengketakan dengan mengedepankan musyawarah dan kekeluargaan hingga pada akhirnya bisa tercapai suatu perdamaian antara pihak yang bersengketa. Ketentuan dalam Pasal 20 ayat (1) Peraturan Bank Indonesia Nomor 7/:46/PBI/2005 tentang Akad Penghimpunan dan Penyaluran Dana bagi Bank yang Melaksanakan Kegiatan Usaha Berdasarkan Prinsip Syariah menyatakan bahwa :

"Dalam hal salah satu pihak tidak memenuhi kewajibannya sebagaimana diperjanjikan dalam akad atau jika terjadi perselisihan di antara bank dan nasabah maka upaya penyelesaian dilakukan melalui musyawarah."

Demikian pula dipertegas lagi dalam ketentuan Pasal 4 ayat (1) Peraturan Bank Indonesia Nomor: 9/19/PBI/2007 tentang Pelaksanaan Prinsip syariah dalam Kegiatan Penghimpunan Dan adanya Penyaluran Dana serta Pelayanan Jasa Bank Syariah , bahwa:

"Dalam hal salah satu pihak tidak memenuhi kewajibannya sebagaimana tertuang dalam akad antara bank dengan nasabah, atau jika terjadi sengketa antara bank dengan nasabah, penyelesaian dilakukan melalui musyawarah."

Islam sebagai sebuah agama lebih mencintai perdamaian dan menjadi pedoman bagi pemeluk-pemeluknya. Dalam hal sengketa muamalah yang timbul akan lebih utama jika diselesaikan melalui cara-cara damai. Untuk itu para pihak sebaiknya lebih mengedepankan menempuh upaya musyawarah untuk mufakat ketika menghadapi sengketa. Melalui upaya dialogis ini diharapkan hubungan bisnis dan persaudaraan yang ada dapat tetap terjalin dan lebih dapat menjaga

2. Penyelesaian Sengketa Melalui Mediasi Perbankan

Dalam Pasal 1 angka 5 Peraturan Bank Indonesia Nomor 8/5/PBI/2006 tentang Mediasi Perbankan sebagaimana telah diubah dengan Peraturan Bank Indonesia Nomor 10/1 /PBI/2008 menyatakan bahwa penyelesaian sengketa perbankan syariah mediasi 
perbankan sesuai peraturan perundang- undangan yang berlaku, Sehinggap jika tidak dapat titik temu dalam musyawarah maka para pihak berperkara dapat menunjuk seseorang bertindak sebagai penengah (mediator), yang akan menengahi penyelesaian sengketa perbankan syariahnya. Yang apabila terlah terjadi kesepakatan maka dituangkan dalam akta kesepakatan yang ditanda tangani oleh pihak nasabah dan bank.

\section{Penyelesaian Sengketa Melalui Basyarnas}

Dalam Pasal 20 ayat (2) Peraturan Bank Indonesia Nomor 7/46/PBI/ 2005 tentang Akad Penghimpunan dan Penyaluran Dana bagi Bank yang Melaksanakan Kegiatan Usaha Berdasarkan Prinsip Syariah menyatakan bahwa :"Dalam hal musyawarah tidak mencapai kesepakatan maka penyelesaian lebih lanjut dapat dilakukan melalui alternatif penyelesaian sengketa atau Badan Arbitrase Syariah."Berdasar ketentuan dalam Pasal 4 ayat (3) Peraturan Bank Indonesia Nomor 9/19/PBI/2007 tentang Pelaksana an Prinsip Syariah dalam Kegiatan Penghimpunan Dan adanya Penyaluran Dana serta Pelayanan Jasa Bank Syariah, penyelesaian sengketa perbankan syariah melalui mekanisme arbitrase syariah baru dapat dilakukan jika penyelesaian sengketa melalui mediasi, termasuk mediasi perbankan tidak mencapai kesepakatan.

4. Penyelesaian Sengketa Melalui Pengadilan Agama

Pengaturan mengenai penyelesaian sengketa antara pemegang kartu dengan pihak bank penerbit juga tercantum dalam Fatwa Dewan Syariah Nasional Nomor 54/DSN-MUI/X/2006 tentang Syariah Card bagian kctujuh yaitu:

"Jika salah satu pihak tidak menunaikan kewajibannya atau jika terjadi perselisihan di antara pihak-pihak terkait maka penyelesaiannya dapat diakukan melalui Badan Arbitrase Syariah atau melalui Pengadilan Agama setelah tidak tercapai kesepakatan melalui musyawarah."

Lalu ditambah dengan Undang-Undang Nomor 21 tahun 2008 tentang perbankan syariah pasal 55(1) "Penyelesaian sengketa perbankan syariah dilakukan oleh pengadilan dalam lingkungan peradilan agama " adapun lanjutan pasal tersebut terkait dengan penyelesaian diluar dari pasal 55 (1) maka diselesaikan sesuai dengan akad perjnjian yang telah dibuat.

Dari sini dapat dilihat adanya asas kebebasan berkontrak antara para pihak yang bersepakat dalam sebuah akad, dimana penyelesaian akan suatu kejadian yang merugikan para pihak dapat diselesaikan berdasarkan pada isi akad tersebut. akan tetapi ini tidak bersifat mutlak dikarenakan kewenangan dari peradilan agama yang diatur dalam pasal Undang-undang peradilan agama salah satu isinya berisikan Pasal 49 Undang-Undang 
Peradilan Agama, maka dapat disimpulkan bahwa sengketa di bidang ekonomi syariah yang menjadi kewenangan Pengadilan Agama adalah :

a. Sengketa di bidang ekonomi syariah antara lembaga keuangan dan lembaga pembiayaan syariah dengan nasabahnya;

b. Sengketa di bidang ekonomi syariah antara sesama lembaga keuangan dan lembaga pembiayaan syariah;

c. Sengketa di bidang ekonomi syariah antara orang-orang yang beragama Islam, yang mana dalam akad perjanjiannya disebutkan dengan tegas bahwa kegiatan usaha yang dilakukan adalah berdasarkan prinsip-prinsip syariah hukum Islam.

\section{Kesimpulan}

1. Kafalah pada dasarnya adalah akad sukarela yang bernilai ibadah bagi penjamin karena termasuk kerja sama dalam kebajikan, dan penjamin berhak meminta gantinya kembali kepada terutang, sepantasnyalah ia tidak meminta upah atas jasanya tersebut, agar aman/jauh dari syubhat.

2. Untuk menyelesaikan sengketa yang terjadi dalam transaksi syariah card ini, ada beberapa cara yang dapat ditempuh oleh para pihak yaitu dengan cara non litigasi melalui musyawarah, mediasi perbankan, ataupun melalui Badan Arbitrase Syariah Nasional (Basyarnas), atau dengan menempuh jalur litigasi melalui Pengadilan Agama. 


\section{Daftar Bacaan}

Buku :

Baaysir, Ahmad Azhar, Azas-azas Hukum Muamalah, Yogyakarta, UII Press, 2004

Harahap, M. Yahya, Arbitrase, Edisi kedua, Cetakan ketiga, Jakarta: Sinar Grafika, 2004.

Subekti, R dan R. Tjitrosudibio, Terjemahan Kitab Undang-Undang Hukum Perdata (Burgerlijk Wetboek), Pradnya Paramita, Jakarta, 1992.

Sholihin, Ahmad Ifham, Buku Pintar Ekonomi Syariah, Gramedia Pustaka Utama, Jakarta, 2010.

Usman, Rachmadi, Pilihan Penyelesaian Sengketa di Luar Pengadilan, Citra Aditya Bakti, Bandung, 2003.

Peraturan Perundang - undangan :

Undang-Undang Republik Indonesia Nomor 30 Tahun 1999 tentang Arbitrase dan Alternatif Penyelesaian Sengketa, Lembaran Negara Nomor 138 Tahun 1999, Tambahan Lembaran Negara Nomor 3871.

Undang-Undang Republik Indonesia Nomor 3 Tahun 2006 tentang Perubahan Atas

Undang-Undang Nomor 7 Tahun 1989 tentang Peradilan Agama, Lembaran Negara Nomor 22 Tahun 2006, Tambahan Lembaran Negara Nomor 4611.

Peraturan Bank Indonesia Nomor : 7/46/PBI/2005 tentang Akad Penghimpunan dan

Penyaluran Dana Bagi Bank Yang Melaksanakan Kegiatan Usaha Berdasarkan

Prinsip Syariah, Lembaran Negara Nomor 124 Tahun 2005, Tambahan

Lembaran Negara Nomor 4563

Fatwa dewan syariah nasional :

Fatwa Dewan Syariah Nasional Nomor 11/DSN-MUI/IV/2000 tentang Kafalah.

Fatwa Dewan Syariah Nasional Nomor 54/DSN-MUI/X/2006 tentang Syariah Card. 